\title{
Medytacja alegoryczna na przykładzie Fascykułu nabożeństwa różnego Adama Opatowiusza
}

Fascykut nabożeństwa różnego panien zakonu św. Klary... przy kościele św. Andrzeja w Krakowie jest dziełem krakowskiego księdza Adama Opatowiusza (1574-1647), profesora i wieloletniego rektora Akademii Krakowskiej, który w latach 1626-1647 pełnił funkcję ojca duchowego krakowskich klarysek ${ }^{1}$. Dzieło zostało wydane w Krakowie w roku 1633 i przez wiele lat służyło jako podręcznik życia zakonnego u córek św. Klary². Stanowi obszerny zbiór rozmyślań podejmujących problematykę życia zakonnego, a także odnoszących się do roku liturgicznego ze szczególnym uwzględnieniem świętych zakonu franciszkańskiego. Od strony teologicznej wykazują wpływ tradycji ignacjańskiej oraz teologii św. Bernarda, św. Bonawentury czy Tomasza à Kempis, zawierając wyraźnie ukształtowany program chrystocentryczny.

Z dojrzałością teologiczną łączy się tu biegłość retoryczna pozwalająca odpowiednio wykorzystać elementy sztuki wymowy do osiągnięcia celów związanych z kierownictwem duchowym. Retoryka jako zespół środków służących przekonaniu kogoś do przyjęcia określonej postawy została zastosowana w szczególnym procesie perswazji, jaki dokonywał się w obrębie medytacji. Założeniem tego typu modlitwy jest bowiem pomoc w trudnym procesie postępowania drogą zjednoczenia z Bogiem, gdzie tekst oddziałuje na życie wewnętrzne, stanowiąc rodzaj „mowy” skierowanej do duszy. Analiza alegorii i alegorezy ${ }^{3}$ pozwoli ukazać sposób uczestnictwa ele-

${ }^{1}$ Zob. J. Bukowski, Adam Opatovius, dawny akademik krakowski, „Przegląd Katolicki” 38 (1900), s. 274 (dzieło Opatowiusza dalej cytowane jako Fascykut).

${ }^{2}$ Istnieje świadectwo F. Brachy, że medytacje Fascykułu były wykorzystywane jeszcze w 1947 roku, czyli w trzysta lat po śmierci Opatowczyka - zob. F. Bracha, Adam Opatowski (1574-1647). W 300-letnia rocznice śmierci, „Nasza Przeszłość” 3 (1947), s. 125. Szerzej na temat Fascykułu zob. M. Godawa, Bogomyślność. Zagadnienie zjednoczenia człowieka z Bogiem w medytacji na podstawie «Fascykułu nabożeństwa różnego» Adama Opatowiusza, Kraków 2006.

${ }^{3}$ Alegoreza jest pojęciem dwudziestowiecznym oznaczającym umiejętność interpretacji, odczytywania alegorii - zob. Stownik literatury staropolskiej, red. T. Michałowska, Wro- 
mentów komunikacji retorycznej w dynamice spotkania człowieka z Bogiem zawartej w dziele Adama z Opatowa.

Dla tej analizy ważne będzie przywołanie dwóch teorii alegorii: retorycznej i biblijnej. W pierwszej alegoria jest figurą myśli (figura sententiarum) zbudowaną z planu znaczeń dosłownych (słowa i rzeczy w znaczeniu dosłownym) i planu znaczeń właściwych wprowadzonych dzięki decyzji nadawcy, tak że znaczenie dosłowne jest członem określającym (rematem, determinans), natomiast znaczenie podstawione, właściwe stanowi człon określany (temat, determinandum $)^{4}$. Alegoria zawiera przyporządkowanie jednorazowe właściwe dla konkretnej sytuacji i w tym kontekście ujawnia się zależność konstrukcji alegorii od intencji autora, gdyż może on przyporządkowywać elementy planów w sposób zupełnie zaskakujący dla czytelnika, który porusza się w zmienionym kręgu kulturowym. Inną istotną cechą omawianej figury jest fakt, że „działa i przemawia jako struktura oraz jako zbiór części”. Zatem obok znaczenia nadrzędnego występują w niej znaczenia partykularne oddające aspekty całościowej sytuacji ${ }^{5}$.

Drugą tradycją czytania alegorii jest biblijna teoria sensów (noematyka). „Alegoria nie jest tu jedną z figur myśli przez immutację - pisze Jerzy Ziomek - lecz tworzy układ komplementarny w czworakim sposobie czytania i rozumienia słów i zdarzeń"6. Źródłem tej tradycji jest starożytność chrześcijańska. Dokument Papieskiej Komisji Biblijnej pt. Interpretacja Pisma Świętego w Kościele stwierdza: „Egzegeza starożytna [...] w każdym tekście Pisma Świętego dopatrywała się wielu poziomów znaczeniowych. Najczęściej dokonywano rozróżnienia sensów na dosłowny i duchowy. Egzegeza średniowieczna ukazywała trzy różne aspekty sensu duchowego, które dotyczyły: znaczenia prawdy objawionej, sposobu wprowadzania jej w życie i ostatecznego dopełnienia. Stąd wziął się sławny dystych Augustyna z Danii (XIII w.): Littera gesta docet, quid credas allegoria, moralis quid agas, quid speres anagogia" . W interpretacji Pisma Świętego można więc wyróżnić sens literalny (sensus litteralis, sens historyczny)

cław 1990, s. 23, por. J. Ziomek, Retoryka opisowa, Wrocław 1990, s. 240. Cechą charakterystyczną Fascykułu jest dokonywanie tego zabiegu przez autora.

${ }^{4}$ Związek rematu i tematu opiera się na podobieństwie (similitudo), a nie na przyległości znaczeń, co łączy alegorię z metaforą i porównaniem, a różni od symbolu. Alegoria zawsze zbudowana jest na porównaniu, chociaż wskaźnik ,jak” może zostać opuszczony. W metaforach i porównaniach związek określania jest bliższy, podczas gdy w prawach rządzących alegorią rzeczywiste podobieństwo rematu i tematu może być w większym stopniu zastąpione przez intencję autora - zob. J. Ziomek, Retoryka opisowa, dz. cyt., s. 241.

${ }^{5}$ Zob. tamże, s. 240-241.

${ }^{6}$ Tamże, s. 244.

${ }^{7}$ Papieska Komisja Biblijna, Interpretacja Pisma Świętego w Kościele, Poznań 1994, s. 66. 
oraz sens duchowy (sensus spiritualis), który posiada trzy znaczenia: alegoryczne - przedstawiające prawdę wiary, moralne - określające zasady postępowania oraz anagogiczne - odnoszące się do ostatecznego wypełnienia Bożych planów, czyli do eschatologii. Alegoria jest w tym kontekście jedną z odmian sensu duchowego pozwalającą wydobyć z sensu dosłownego ukryte znaczenie Pisma Świętego. O związku sensów mówi św. Tomasz z Akwinu: „Omnes sensus fundentur super litteralem”, co oznacza, że każdy rodzaj sensu duchowego powinien wynikać z sensu dosłownego. W ten sposób harmonia sensów zapewnia szczególne bogactwo lektury tekstu natchnionego'.

Adam Opatowiusz z racji wykształcenia korzystał z obydwu tradycji. W trakcie szkolnej edukacji uczył się obowiązkowej wtedy retoryki klasycz$n^{1} j^{10}$, natomiast w ramach studiów teologicznych poznawał zasady i przykłady alegorycznej interpretacji Biblii. Obydwa sposoby lektury wykorzystał następnie w swej pracy kierownika duchowego, czego owocem jest $\mathrm{Fa}$ scykut. O ile jednak kryterium alegorezy retorycznej były po prostu sensowność wypowiedzi i zasada decorum dające wielką swobodę kombinacji, o tyle w objaśnianiu Pisma Świętego autor musiał ściśle respektować autorytet Kościoła, o czym przypomniał Sobór Trydencki ${ }^{11}$, jakkolwiek i w tym zakresie możliwość zaskakujących eksplikacji była duża. Dokument Papieskiej Komisji Biblijnej przypomina, że egzegeza „próbowała doszukiwać się sensu duchowego w najmniejszych szczegółach tekstów biblijnych”, by następnie stwierdzić, że nowożytna egzegeza „nie może się zgodzić na przypisywanie tym próbom aż takich wartości interpretacyjnych, choć mogły one

${ }^{8}$ Św. Tomasz z Akwinu, Summa theologiae, I, 1, 10 ad 1, [cyt. za:] Katechizm Kościoła Katolickiego, Poznań 1994, art. 116, s. 39.

${ }^{9}$ Por. Katechizm Kościoła Katolickiego, dz. cyt., art. 115, s. 39.

${ }^{10} \mathrm{~W}$ baroku autorzy reprezentowali różne poglądy stylistyczne. Akademia Krakowska stała na straży cyceronianizmu, podczas gdy w kolegiach jezuickich nauczano stylu barokowego - zob. Źródta wiedzy teoretycznoliterackiej w dawnej Polsce, red. M. Cytowska, T. Michałowska, Warszawa 1999, s. 68-69.

${ }^{11}$ Ojcowie soboru w dokumencie pt. Dekret II. Przyjęcie Wulgaty i zasady interpretacji Pisma Świętego stwierdzają: „Ponadto dla powściągnięcia niektórych zuchwałych umysłów [Sobór] oświadcza, by nikt, kto polega na własnej roztropności w rzeczach dotyczących wiary i moralności, a wchodzących w skład nauki chrześcijańskiej, i kto nagina Pismo św. do swoich poglądów - nie ośmielił się dawać objaśnień Pisma św. wbrew sensowi, który utrzymywała i utrzymuje święta Matka Kościół. Rzeczą bowiem Kościoła jest sądzić o prawdziwym sensie i tłumaczeniu Pisma św. Niech nikt także nie komentuje Pisma św. wbrew powszechnej zgodzie Ojców, chociażby jego komentarze nie miały ujrzeć światła dziennego. Tych, którzy by się temu opierali, niech ich ordynariusze wytkną i ukarzą karami przewidzianymi przez prawo" - zob. Breviarium Fidei. Wybór doktrynalnych wypowiedzi Kościoła, Poznań 1997, s. 117. Adam Opatowiusz, wierny nauczaniu Kościoła i znany ze swej prawości, nie tylko miał świadomość tych zasad, ale także do nich się stosował. 
przynosić w przeszłości pewne korzyści pastoralne"12. Jakkolwiek dokument opisuje praktykę starożytną, wydaje się, że uwaga o korzyściach pastoralnych osiąganych kosztem ścisłego wynikania sensów może być przydatna w odczytywaniu niektórych alegorii Opatowiusza.

Ze względu na różnorodność alegorii, która ma źródło w retorycznej i biblijnej genezie, należy przyjąć w ich opisie kryterium porządkujące. Opiera się ono na strukturze rematyczno-tematycznej, w której sens dosłowny czy też poziom rzeczy dosłownych jest rematem określającym znaczenie właściwe figury, bądź też - w lekcji egzegetycznej - sens duchowy, a zwłaszcza jego wersję alegoryczną. Otóż wszystkie alegorie analizowanego dzieła można podzielić na takie, w których rematem jest tekst biblijny i takie, gdzie jest nim jakiś element szeroko pojętego ludzkiego doświadczenia. W obydwu przypadkach tematami mogą być z jednej strony sensy biblijne, a z drugiej - doświadczenie duchowe. Można zatem przyjąć istnienie czterech typów alegorii: biblijno-biblijnej, biblijno-doświadczalnej, doświadczalno-biblijnej oraz doświadczalno-doświadczalnej, gdzie pierwszy wyraz określa remat, a drugi - temat.

\section{Alegorie biblijno-biblijne}

W tej alegorii jeden tekst biblijny służy do ukazania ukrytych znaczeń drugiego. Przykładem jest przedstawienie męki Chrystusa za pośrednictwem elementów ze sceny rozmnożenia chleba będącej punktem wyjścia całej medytacji. Autor w swej wykładni trzy składniki znaczeniowe odnosi do realiów Golgoty i stwierdza, że dzieckiem przynoszącym chleby i ryby „nie kto inszy jest, jedno ty sam, Panie Jezu, bo w osobie dziecięcia na tym świecie stawiłeś się i w niewinności [...] żyłeś". Następnie podaje dalszy ciąg swej eksplikacji: „Pięcioro chleba jest pięć ran w Ciele twoim, a dwie rybce jest Dusza i Ciało twoje, oboje dwojakim ogniem miłości i boleści na Krzyżu upieczone"13. Autorskie uzasadnienie jest oparte na dość swobodnym podobieństwie, a uzyskane znaczenie prowadzi do prośby, aby Chrystus swoimi rękami podzielił ten pokarm (tj. mękę) i aby był on podany zakonnicom przez ich duchową matkę, czyli bł. Salomeę, która występuje w roli apostoła karmiącego chlebem. Charakterystyczną cechą objaśniania tekstów biblijnych przez inne teksty biblijne jest współwystępowanie z nimi objaśnień odnoszących się do doświadczenia, zbudowanych na tym samym fundamencie skrypturystycznym.

${ }^{12}$ Papieska Komisja Biblijna, Interpretacja Pisma Świętego w Kościele, dz. cyt., s. 71. Termin „egzegeza nowożytna” odnosi się do czasów współczesnych powstaniu dokumentu, o czym świadczy użycie czasu teraźniejszego.

${ }^{13}$ Fascykut, s. 416-417. 
Warto zwrócić uwagę na wykorzystanie obrazu triumfalnego wjazdu Chrystusa do Jerozolimy do uwidocznienia dramatu Jego drogi krzyżo$w^{14}{ }^{14}$. Realistycznemu znaczeniu wjazdu odpowiada następująca eksplikacja: „O Panie Jezu, [...] teraz sam jesteś Osiełkiem u krzyża”. Następnie motywy zaczerpnięte $\mathrm{z}$ wjazdu służą do przedstawienia rzeczywistości prowadzenia życia sakramentalnego i w tej relacji autor raz jeszcze sięga po motyw osiołka: „Tęż dwojaką Procesją odprawujesz, kiedy w osobach Chleba Naświętszego Sakramentu jako na Osiełku jakim jedziesz do serca mojego" "15. Ostatnie znaczenie, nawiązując do poprzednich, tworzy trzeci człon, w którym ma miejsce aktualizacja treści biblijnych wyrażająca się szczególnie w bogactwie sensów moralnych ${ }^{16}$.

Powyższe przykłady pozwalają na wysnucie wniosków dotyczących konstruowania spójności tekstów poprzez alegorie. W Fascykule autor buduje medytacje, rozwijając alegorycznie znaczenia zawarte w cytacie inicjalnym. Alegoria biblijno-biblijna nie posiada jednak wartości autonomicznej, gdyż jest dopełniana wyjaśnieniem (alegorezą) biblijno-doświadczalnym odnoszącym sens biblijny do sytuacji odbiorcy. Punktem wyjścia jest ten sam inicjalny cytat, co stanowi o tożsamości rematu w obydwu sytuacjach, chociaż nie jest wykluczone, że w obydwu nurtach dadzą się zauważyć różnice uzależnione od stosunków znaczeniowych między poszczególnymi planami.

Opatowiusz zwykle najpierw prowadzi alegorezę biblijno-biblijną, która służy rozważeniu treści, co ma prowadzić do ich lepszego przyswojenia. Natomiast lekcja biblijno-doświadczalna ma na celu przeniesienie tych znaczeń w rzeczywistość odbiorcy. Obydwa typy alegorii wiążą się z porządkiem udziału władz duszy w medytacji, ponieważ pierwszy bardziej aktywizuje rozum, a drugi wolę ${ }^{17}$. Ta perswazyjna funkcja alegorii okazuje się bardziej istotna od jej stylistycznej czystości, czego świadectwem są pewne niekonsekwencje w budowie figur ${ }^{18}$.

${ }^{14}$ Zob. tamże, s. 456-460. Jakkolwiek zabieg ten ma raczej charakter zestawienia podobnych i przeciwstawnych motywów, zawiera także elementy alegoryczne, zwłaszcza motyw osiołka.

${ }^{15}$ Fascykut, s. 458.

${ }^{16}$ Por. tamże, s. 459, gdzie został sformułowany postulat zrzucania z siebie grzechów na podobieństwo szat zdejmowanych w czasie procesji.

${ }^{17}$ Następstwo zastosowania w medytacji woli w oparciu o działanie rozumu jest charakterystyczną cechą medytacji Fascykułu, wykazującą związki z metodą trzech władz duszy Ignacego Loyoli - por. M. Godawa, Bogomyślność..., dz. cyt., s. 58-73, 88-99.

${ }^{18} \mathrm{~W}$ operowaniu motywami sceny rozmnożenia chleba zwracała uwagę swoboda motywowania porównań tworzących alegorię. Relacja procesji do Jerozolimy do drogi krzyżowej obok elementów alegorycznych zawiera także zestawienia oparte nie na podobieństwie, a na kontraście, jak np. okrzyki „Hosanna” i bluźnierstwa przeciw Jezusowi. W tej samej intencji autor dokonuje zestawienia par pojęć, np. tłumu z jednego i drugiego wydarzenia, gdzie rów- 


\section{Alegorie biblijno-doświadczalne}

Materiał biblijny często służy Opatowiuszowi za tworzywo alegorii opisujących doświadczenia życia duchowego. Ten rodzaj zawiera wiele rozbudowanych figur, które stanowią oś medytacji, a poszczególne znaczenia partykularne odpowiadają punktom rozmyślania.

Jako przykład można wskazać na ciekawą grupę figur, których rematy pochodzą z Księgi Wyjścia. Scena spotkania Mojżesza z Bogiem na pustyni została wykorzystana do opisu „bogomyślności”, czyli zakonnej modlitwy myślnej. Wybrane elementy biblijnego obrazu tworzą pięć punktów medytacji zaznaczanych w tekście łacińskimi cytatami. Najpierw autor przypomina, że Mojżesz był pasterzem owiec, i od razu dodaje swą wykładnię, że dusza też jest pasterką, zaś jej trzodami są akty myśli, woli i pamięci, a także używanie zmysłów: wzroku, słuchu, powonienia, smaku i dotyku. W tym kontekście formułuje negatywną ocenę postępowania duszy. Drugi punkt zawiera rozważanie o wygnaniu trzód przez Mojżesza na pustynię, co w znaczeniu alegorycznym oznacza poddanie władz duszy i zmysłów („trzód”) modlitwie medytacji określonej jako „pustynia bogomyślności, opłakiwania grzechów”19. Trzecim elementem jest ukazanie się Boga „w płomieniu ognia z pojśrzodku krzaku”20, a jest on rozwijany w następujący sposób: ogniem jest sam Pan Jezus i Jego miłość ujawniona szczególnie na krzyżu. Dzięki temu obraz płomienia pośród krzaku kojarzy się ze Zbawicielem w koronie cierniowej. Obok tego dosłownego znaczenia cierni autor przedstawia też przenośne: krzak oznacza w ogóle Jezusowe rany i cierpienie ${ }^{21}$. W czwartym punkcie Opatowczyk pisze, że jak Mojżesz opuszcza trzody, by iść oglądać „widok wielki”, tak dusza ma porzucić swe trzody, które tutaj oznaczają miłość własną i życie afektywne, by oglądać Boga, zwłaszcza Jego mękę. W porównaniu do pierwszego punktu zmieniona została eksplikacja trzody, gdyż neutralny opis składników ludzkiej natury został zastąpiony elementami o ujemnym wartościowaniu (miłość własna, afekty). Raz jeszcze świadczy to o swobodzie pod-

nież nie działa mechanizm zmiany znaczenia. Trzeba też dodać, że Opatowiusz chętnie łączy alegorie z innymi środkami stylistycznymi. Także alegoria lilii między cierniami jako głowy Chrystusa w koronie cierniowej z jednej strony zawiera dosłowne, a nie przenośne, jak powinno być w alegorii, znaczenie cierni, a z drugiej została dopełniona aluzją, kiedy bowiem autor mówi, że teraz, tzn. na krzyżu, Jezus ma gdzie skłonić głowę, odwołuje się do Jego własnych słów (por. Mt 8, 20), chociaż są one potraktowane przenośnie, oddając w przejmujący sposób powagę sytuacji - zob. Fascykul, s. 494-495.

${ }^{19}$ Fascykut, s. 405.

${ }^{20}$ Tamże, s. 406.

${ }^{21}$ Zob. tamże. Opatowiusz zakłada tu utożsamienie cierni z krzakiem oparte na związku przyległości (metonimii). 
kładania znaczeń (immutacji) uzależnionej od tego, co nadawca chce przekazać w zakresie kierownictwa duchowego. Wreszcie w punkcie piątym przedmiotem uwagi staje się Ziemia Święta i nakaz pozostawienia obuwia. Na poziomie rzeczy w znaczeniu właściwym ziemia oznacza miejsce modlitwy ${ }^{22}$, natomiast obuwie, które należy zdjąć ze względu na świętość miejsca, oznacza, podobnie jak w punkcie czwartym, negatywne cechy życia, tj. ,affekty”, nałogi, gniew, nienawiść, powrót do grzechu, które należy odrzucić. Genezą tej eksplikacji jest wielkopostny charakter medytacji. Historia Mojżesza służy autorowi do przedstawienia aspektów modlitwy, zaś alegoryczne objaśnienia łączą się wyraźnie w obrębie sensu duchowego z moralnym znaczeniem tekstu.

Ten sam tekst biblijny służy też do wyprowadzenia innych znaczeń dotyczących przygotowania do „bogomyślności”. Rozmyślanie to zbudowane jest z czterech punktów ${ }^{23}$. Na początku autor interpretuje krzak ognisty jako obrazowe przedstawienie istoty tej modlitwy. Ogólnie krzak oznacza duszę człowieka, natomiast bardziej szczegółowo wśród konotacji tego słowa zostały wskazane następujące cechy: jest on „nikły i podły”, „niepłodny”, „nie nadaje się na budulec”, a każda z nich oznacza pewien negatywny aspekt życia duchowego ${ }^{24}$. Szczególnie istotna jest konotacja: „krzak służy ogniowi”, w oparciu o którą autor mówi o ogarnięciu duszy Bożą miłością na wzór płonącego krzaka. W porównaniu z poprzednim tekstem utrzymane zostało znaczenie ognia jako miłości, natomiast „krzak” otrzymał inne znaczenie właściwe (natura ludzka). W punkcie drugim, pisząc o godności „bogomyślności”, jako człon określający (determinans) autor wybiera fakt, że krzak płonąc, nie spalał się, i na tej podstawie konsekwentnie wyraża prawdę, iż obecność Boga (ogień) nie niszczy natury człowieka (krzak). W dalszej kolejności został podjęty motyw zrzucania obuwia, który tu odnosi się do ciała, „affektów” i nałogów, przy czym każda z tych relacji jest pomysłowo umotywowana. Obuwie wykonuje się ze skór bydląt, a ciało jest „bydlętom równe”, obuwie ubiera się przed drogą, a dusza przed popełnianiem grzechu ,pierwej się w affekt obuje”, wreszcie jak człowiek przyzwyczaja się do noszenia obuwia, tak wiąże się przez nałóg

${ }^{22}$ Zob. Fascykut, s. 408.

${ }^{23}$ Zob. tamże, s. 112-117.

${ }^{24} \mathrm{Z}$ podobnych ujęć można wymienić rozbudowaną alegorię, w której „Cedr Libański” oznacza Maryję, natomiast dodane przez autora „krzaczki” (umotywowane zresztą tekstem inicjum) odnoszą się do sióstr zakonnych. Zestawienie cech znaczeniowych tych przedmiotów określa rolę Maryi we wspólnocie zakonnej - zob. Fascykut, s. 947-948. Także inny tekst rozwijający przypowieść o winnicy (por. Mt 21, 33-45) wyjaśnia winnicę jako duszę, jednak w kontekście powołania zakonnego. W ten sposób typowe objaśnienie biblijne zostaje przez autora zmodyfikowane. 
z grzesznym życiem. W zakończeniu pojawia się twierdzenie, że „w bogomyślności są rozmaite nadchnienia”, przy czym elementy mowy Boga (natchnienia) z Księgi Wyjścia też mają swój alegoryczny sens, gdyż Egipt oznacza grzech, a miejsce po jego opuszczeniu - „swobodę życia Zakonnego". W ten właśnie sposób alegorie biblijno-doświadczalne, organizując przebieg medytacji, odnoszą się do realiów życia zakonnego.

\section{Alegorie doświadczalno-biblijne}

Trzecią z rozważanych relacji jest budowanie alegorii poprzez zastosowanie rematów zaczerpniętych $\mathrm{z}$ doświadczenia do lepszego przedstawienia treści biblijnych.

W jednej z medytacji na temat męki Pańskiej autor punktem wyjścia czyni słowa z Pieśni nad Pieśniami: „Introduxit me Rex in Celaria sua...”, co zostało przełożone jako: „Wprowadził mię Król do pokojów swoich...”. Biblia Tysiąclecia podaje tłumaczenie: „Wprowadź mnie, królu, w twe komnaty" (Pnp 1,4). Tekst biblijny mówi więc o mieszkalnych pomieszczeniach królewskiego pałacu, natomiast autor używa w ich miejsce słowa „sklepy" w znaczeniu miejsc służących przechowywaniu towarów i handlowaniu nimi. W ten sposób wprowadza w lekturę treści biblijnych element doświadczenia codzienności, odsuwając się od znaczeń sugerowanych przez tekst Pieśni nad Pieśniami.

W znaczeniu ogólnym męka Zbawiciela przedstawiona jest jako sklepy: „Tajemnice Męki Zbawiciela naszego są to sklepy skryte i nie wszytkim wiadome”. Następnie autor podaje motywację swej alegorii: „W sklepach rzeczy drogie zawierają, a nad Mękę Zbawiciela Kościół Boży nie ma nic droższego"25. Po zaznaczeniu, że takich sklepów może być wiele, wymienia siedem wybranych przez siebie. Są nimi poszczególne elementy męki w porządku chronologicznym. Pierwszy stanowią smutek, lęk i krwawy pot w ogrodzie oliwnym, drugi - ból i wstyd odnoszący się do duszy, ciała, a także dobrego imienia, godności nauczyciela oraz relacji do uczniów i Matki. Trzecim sklepem jest biczowanie i cierniem ukoronowanie, czwartym - ukrzyżowanie, piątym - wstyd obnażenia z szat i umieszczenia między łotrami, szóstym - podeptanie krwi Chrystusa na ziemi, siódmym - pogrzeb Jezusowego ciała. Po tej prezentacji Opatowiusz podaje kolejne znaczenie partykularne: „te sklepy, ponieważ okupienie zbawienia naszego rzecz dziwnie drogą zawierają, muszą być pod czyimś kluczem? Nie pod inszym, jedno pod twoim kluczem Panie Jezu"26. Tu autor wzmacnia swą

\footnotetext{
${ }^{25}$ Fascykut, s. 410.

${ }^{26}$ Tamże, s. 411.
} 
lekcję cytatem z Pisma Świętego: „O clavis David, qui aperis, \& nemo claudit" odniesionym zgodnie z tradycją liturgiczną ${ }^{27}$ do Jezusa. Zastosowanie rematu klucznika do Jezusa połączone z wątkiem biblijnym służy wyeksponowaniu przekonania, że to Chrystus osobiście wprowadza duszę w tajemnice swej męki. Autor wyraźnie zaznacza element obyczajowy, który czyni członem określającym (determinans) swojej alegorii: „kto chce jakiej drogiej kupie dostać, potrzebuje, żeby mu kto sklep drogi pokazał, a potym wszedszy pyta się, na ostatek kupiec jakich jedno chce materyj pokazuje" 28 . Następnie, utrzymując znaczenie duszy jako klienta, Chrystusa określa jako kupca oferującego swe towary. Dusza zakonna potrzebuje bowiem kogoś, kto pokazałby jej towar, a żądanie to zostaje zaspokojone dzięki łasce: „Już to pyta się o drogim towarze boleści, zranienia, smutku i Krzyża Zbawiciela swojego. A miłość Pana Jezusowa jest jako kupiec w tych sklepach, wydając i pokazując te tajemnice wszytkie, o które dusza pyta się i dostanie wszytkiego przez pragnienie gorące serca swojego"29.

Autor wykorzystuje zatem elementy codziennego doświadczenia, odnajdując podobieństwa między aspektami handlu a zgłębianiem w modlitwie tajemnic męki Pańskiej. Zastosowanie alegorii odświeża proces medytacji nad często podejmowanym tematem. Poprzez wskazanie związków znaczeniowych dokonuje się też podkreślenie (amplifikacja) treści biblijnych, ponieważ autor każe zwrócić uwagę na te elementy sceny biblijnej, które wchodzą w alegoryczne oddziaływanie. Tak opracowana medytacja zawiera ukryte, ale wyraźnie funkcjonujące sugestie lektury i staje się tym samym szczególną perswazją, wspomagając też proces zapamiętywania.

Omawiana alegoria tylko w pierwszej swej części służy bezpośrednio ukazywaniu znaczeń biblijnych, w drugiej natomiast traktuje o ludzkim postępowaniu, przybierając charakter alegorii doświadczalno-doświadczalnej. Przejście to dokonuje się jednak płynnie, a znaczenia drugiej części opierają się na ustaleniach pierwszej. Tak oto szeroka alegoria umożliwia przejście od rozważań biblijnych do refleksji nad doświadczeniem duchowym i postawami duszy wobec Bożej miłości. Jej użycie zapewnia spójność myślenia, również poziom stylistyczny służy poziomowi wnioskowania. Podobnie jak w wypadku omawianych wyżej alegorii i tutaj pierwsza część rozważań utrzymana w schemacie doświadczalno-biblijnym aktywizuje szczególnie władzę rozumu wspomaganą oczywiście wyobraźnią,

\footnotetext{
${ }^{27}$ „O tobie bowiem mówi Pismo i Kościół śpiewa...” - Fascykuł, s. 411-412.

${ }^{28}$ Tamże, s. 412.

${ }^{29}$ Tamże.
} 
w drugiej natomiast poprzez sam fakt odwołania się do sytuacji duszy perswazja zwraca się ku woli ${ }^{30}$.

\section{Alegorie doświadczalno-doświadczalne}

Ostatni typ alegorii, w którym elementy ludzkiego doświadczenia są wykorzystywane jako człony określające aspekty doświadczenia duchowego, stanowi duży i interesujący zbiór. Zasadniczo alegorie tego typu można podzielić na rozbudowane, ogarniające większy zakres problematyki duchowej oraz krótkie i celne obserwacje.

W pierwszej grupie znajdują się figury, które w interesujący sposób poruszają zagadnienia życia wewnętrznego w kontekście zakonu. Na przykład działanie władz duszy w medytacji opisuje alegoria prasy ${ }^{31}$. Dwie części prasy stanowią władze rozumu i woli; gronami, czyli materiałem rozmyślania są trzy tematy: grzechy i „,affekty”, cierpliwość Chrystusa oraz niezachowywanie reguły. Odpowiadają im kolejno trzy płyny uzyskane jako efekt oddziaływania prasy na grona: „maść skruchy, żalu i łzy”, „olej miłości P.[ana] Boga”, a także „sok pragnienia, stanowienia”. One z kolei tworzą , trojaki olej” mający moc leczenia wszystkich potrzeb duszy zakonnej.

W jednej alegorii nadawca ujmuje syntetycznie szeroką gamę zagadnień i problemów. Wyzyskanie związków znaczeniowych planu określającego (tj. sposobu działania prasy) pozwala na oddanie relacji zachodzących w modlitwie. W ten sposób figura staje się zwięzłym schematem porządkującym myślenie odbiorcy i będącym punktem odniesienia dla jego postępowania. Można jeszcze zwrócić uwagę na sięganie po znaczenia ewokujące „wysiłek” i „samoograniczenie”, gdyż do takich należy pojęcie „prasy”. W naturalnym porządku są one dla odbiorcy trudnym wyzwaniem i potrzebują mocnego uzasadnienia, aby mogły być przyjęte. Jakkolwiek punkt ciężkości tego uzasadnienia spoczywa w motywacji religijnej, czytelność i logika alegorii stwarzają przekonanie, że świat ascezy, do którego się odnoszą, stanowi harmonijną strukturę, w obrębie której dusza może czuć się bezpieczna.

Grupa zwięzłych alegorii doświadczalno-doświadczalnych odznacza się trafnością skojarzeń. Z sięganiem do alegorii Kościoła jako ciała Chrystusa koresponduje wykorzystanie elementów ludzkiego ciała do opisu relacji w zgromadzeniu zakonnym. Poruszając problematykę ślubu posłuszeństwa, autor pisze: „Dwie bowiem nodze są dusze Zakonnej, któremi w po-

${ }^{30}$ Dlatego też w zakończeniu cytowanego tekstu mowa jest o możliwościach serca, które żywi gorące pragnienie poznawania Boga. Te same właściwości można obserwować w alegorii zawartej w medytacji przeznaczonej na tę samą niedzielę Postu - por. Fascykul, s. 398-402.

${ }^{31}$ Zob. tamże, s. 320-321. 
słuszeństwie ma postępować: wolą i rozum"32. Następnie stwierdza niekonsekwencję takiego postępowania, gdy dusza jest „wolą w Zakonie, a rozumem na świecie". W tej ocenie jest zawarte ukryte odwołanie do ścisłej logiki planu znaczeń dosłownych, która zakłada, że nogi przecież działają wspólnie. To oparte na zdrowym rozsądku przekonanie jest traktowane jako model i postulat dla planu znaczeń właściwych, innymi słowy logika rematu określa logikę tematu. Człowiek powinien postępować z taką konsekwencją, jaka ujawnia się w relacjach znaczeń dosłownych. Ponieważ faktycznie tak się nie dzieje, zespół znaczeń dosłownych, doświadczalnych tym silniej ujawnia swój normatywny charakter.

Kiedy indziej Opatowczyk posługuje się elementami ludzkiego ciała w sposób krańcowo odmienny, świadomie naruszając prawa rzeczywistości ${ }^{33}$. Każe sobie wyobrazić „sprosną urodę” człowieka, u którego głowa zajmuje miejsce nóg i na odwrót. Obydwie nazwy oznaczają zarówno elementy natury ludzkiej, odpowiednio - serce i rozum oraz afekty, jak i właściwe im funkcje. Jak głowa powinna kierować nogami, tak rozum powinien panować nad życiem afektywnym. Dla wykazania, że dusza grzesznika zachowuje się inaczej, autor zakłóca logikę w planie rematu i w tym przypadku można postawić znak równości pomiędzy nią a faktycznym stanem rzeczy, co w poprzednio badanej strukturze byłoby właśnie niemożliwe ${ }^{34}$.

Jedną z cech alegorii jest jej pokrewieństwo z przysłowiem i takie brzmienie można odnaleźć w następującym zdaniu: „,kto do wielkiego naczynia żółci kroplę miodu wpuszcza, po staremu żółć gorska"35. Przysłowiu nie towarzyszy jednak eksplikacja, tymczasem Opatowiusz nie omieszkał zaznaczyć, że powierzchowne pociechy nie przyniosą ulgi w stanie potępienia.

Alegorie zbudowane na podstawie biblijnej i doświadczalnej służą Opatowiuszowi do ukazania duchowego sensu Pisma Świętego w kontekście potrzeb duszy poprzez amplifikacje wybranych elementów. Dają sposobność przybliżenia prawd biblijnych i dogmatycznych, a także rozwinięcia refleksji, jej logicznego uporządkowania oraz oddziaływania na wolę podmiotu medytacji. Pozwalają systematyzować myśli i są podstawą organizacji wielu rozmyślań, służąc pomocą w późniejszej memoryzacji treści. Obecność autorskiej wykładni świadczy o intencji nienarażania odbiorcy na niepotrzebne

32 Tamże, s. 159.

${ }^{33}$ Zob. tamże, s. 53. Występuje tutaj typ narracji zwany fabula, czyli fikcją nierealną.

${ }^{34}$ Por. inne zastosowania tego planu znaczeniowego dla uzasadnienia posłuszeństwa zakonnego (Fascykut, s. 156) czy też użycie figury złożonej z elementów ludzkich i zwierzęcych w relacji do problemu temperowania życia afektywnego (Fascykut, s. 566).

${ }^{35}$ Fascykut, s. 56. 
komplikacje w lekturze, z kolei pewne niekonsekwencje stylistyczne i znaczeniowe, a także łatwość łączenia ich z innymi środkami ukazują podporządkowanie aspektu literackiego celom duchowym. Tak przedstawia się znaczenie metody alegorycznej dla modlitwy myślnej w Fascykule Adama Opatowiusza, co w dalszej perspektywie może przyczynić się do pogłębienia badań nad medytacją i jej językiem w „,łłotym wieku polskiej teologii duchowości”.

\section{Analizowane fragmenty: Adam Opatowiusz, Fascykut nabożeństwa różnego..., Kraków 1633}

\section{ALEGORIA BIBLIJNO-BIBLIJNA}

„Jest tu dziecię, które ma pięcioro chleba i dwie rybce pieczone. Tym dziecięciem nie kto inszy jest, jedno ty sam, Panie Jezu, bo w osobie dziecięcia na tym świecie stawiłeś się i w niewinności... tu na świecie żyłeś. Pięcioro chleba jest pięć ran w Ciele twoim, a dwie rybce jest dusza i ciało Twoje, oboje dwojakim ogniem na Krzyżu upieczone" (s. 416-417).

\section{ALEGORIA BIBLIJNO-DOŚWIADCZALNA}

„Pierwsza rzecz znajdowała się w Mojżeszu: był pasterzem owiec. A tyć, duszo moja, pasterką jesteś... Masz od Pana Boga duszę, masz i ciało; na duszy twojej jest rozum, wola i pamięć. O jako trzoda niezliczona myśli rozumu twego... O jako tych żądz nieporachowana trzoda będzie!

Druga rzecz w Mojżeszu: zagnał trzodę swoję w głęboką puszczą. Tak i ty zegnałaś trzody twoje z tej zaraźliwej puszczy świata i zagnałaś je w głęboką pustynią bogomyślności, opłakiwania grzechów twoich. A na tej pustyni ze łzy twoich, które żal za grzechy wytoczył, uczyniłaś łaźnią i w tych trzody twoje kąpałaś je.

Trzecia rzecz znajdowała się w Mojżeszu: pokazał się mu Pan Bóg w płomieniu ognia z pojśrzodku krzaku... O Panie Jezu, ty jesteś tym ogniem i ten ogień jest miłość twoja... kiedyś na Krzyż wstąpił, tam dopiero ten ogień miłości płomieniem wybuchać począł..., kiedyć na głowę wziął krzak ciernia, którym ukoronowany byłeś. Drugi krzak był cięszkiego zranienia, zbicia, który cierniem skrwawionemu ciału równał się.

Czwarta rzecz: w Mojżeszu było pragnienie, tak że mówił te słowa: „Pójdę” i zaraz w tej chęci odchodził od trzody swojej i opuszczał ją... oglądać, co to za tak wielkie widzenie. Tak i ty, o duszo moja, jeśli kiedy tej twarzy ognistej Pańskiej zajrzysz, wzbudźże w sobie pragnienie i zapominając trzód twoich, zwłaszcza tych, które są w ciele twoim, to jest, żebyś... spieszyła się z trzodami rozumu, woli i pamięci twojej... widzieć... Boga w naturze ludzkiej zranionego...

Ostatnia rzecz: te słowa do Mojżesza rzeczone są: „Zrzuć obuwie z nóg, abowiem miejsce, na którym stoisz, ziemią świętą jest”. O duszo moja, dałby to Pan Bóg, aby te słowa w sercu twoim brzmiały, kiedy do uważenia Męki Zbawiciela udajesz się, że miejsce, na którym uważania Męki Zbawiciela czynisz, jest to ziemia święta, bo od zabawy tak świętej poświęcenie bierze... Zrzućże to obuwie ubłocone, to jest wyzuj się ze złych afektów, nałogów, gniewu, nienawiści, przedsięwzięcia wracania się do grzechów i boso, to jest w pokoju, w niewinności serce swoje prowadź do Ukrzyżowanego Zbawiciela” (s. 404-408).

\section{ALEGORIA DOŚWIADCZALNO-BIBLIJNA}

„Cztery rzeczy godne uważenia. Pierwsza: celaria sua. Tajemnice Męki Zbawiciela naszego są to sklepy skryte i nie wszytkim wiadome... W sklepach rzeczy drogie zawierają, a nad Mękę Zbawiciela naszego Kościół Boży nie ma nic droższego i słusznie mówi celaria . 
Druga rzecz: Rex. To jest te sklepy, ponieważ okupienie zbawienia naszego, rzecz dziwnie drogą, zawierają, muszą być pod czyim kluczem. Nie pod inszym, jedno pod twoim kluczem, Panie Jezu. O Tobie bowiem mówi Pismo i Kościół śpiewa: O clavis David, qui aperis, nemo claudit.

Trzecia rzecz: introduxit. To jest, kto chce jakiej drogiej kupie dostać, potrzebuje, żeby mu kto sklep drogi pokazał... Tak która dusza zakonna pragnie zabawę mieć w jakiej tajemnicy Męki Pańskiej, potrzebuje, żeby jej ją kto pokazał i pokazuje łaska Pana Boga...

Czwarta rzecz: exultabimus et laetabimur. W pomieszkaniu tych sklepów zażywa i powierzchownie i wnętrznie wesela" (s. 410-413).

\section{ALEGORIA DOŚWIADCZALNO-DOŚWIADCZALNA}

„[Dusza zakonna] podobna jest prasie. A jako kiedy kto w prasę włoży grono wina i tłoczy, zaraz sok winny płynie, tak rozum i wola, te dwie siele dusze, kiedy uważać poczną, zaraz wdzięczność jako olej, jako droga maść płynie... Niechaj to pierwsze grono będzie jako w prasie duchownej uważania grzechów i afektów... a zatym już popłynie droga maść skruchy, żalu i łzy. Drugie grono - uważanie cierpliwości Pańskiej... i stąd pociece olej miłości Pana Boga. Trzecie grono w tej prasie niech będzie rozważanie niepełnienia reguły, ślubów, obowiązków zakonnych. I stąd popłynie sok pragnienia, stanowienia, że je będzie chciała skutecznie wypełnić. A ten trojaki olej, płynąc, nie tylko głowę dusze zakonnej, ale i wszytkie jej sieły zlewać i leczyć będzie" (s. 321).

\section{Słowa kluczowe}

Alegoreza, alegoria, Biblia, doświadczenie, medytacja, perswazja, retoryka, sensy biblijne, życie duchowe

\section{Summary}

The allegorical meditation on the base of The Fasciculus of various prayer by Adam

\section{Opatowiusz}

This article undertakes the issues of applying the allegorical method of withdrawing meanings from the biblical text during the meditation. It bases on The Fasciculus of various prayer (Fascykut nabożeństwa różnego) by Adam Opatowiusz (1574-1647). The author used the ways of rhetorical allegorization and biblical theory of senses in order to realize the persuasive aims of prayer comprehended as means of spiritual growth. The rhetorical allegorization includes the relation between biblical senses and human experience, which results in four kinds of allegory: the biblical-biblical, biblical-experimental, experimental-biblical and experimental-experimental allegory. It helps in explaining, developing and referring the biblical meanings to spiritual life being also a pivot of reflection whereas the literary elements are subordinated to the spiritual matter.

\section{Keywords}

Allegorization, allegory, Bible, experience, meditation, persuasion, rhetoric, biblical senses, spiritual life 
